ASLI QoL 2021

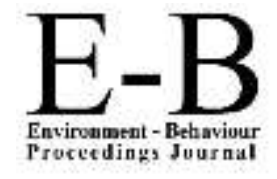

\title{
AQoL2021LangkawiIsland
}

https://www.amerabra.org; https://fspu.uitm.edu.my/cebs; https://www.emasemasresources.com/

$5^{\text {th }}$ ABRA International Conference on Quality of Life

Holiday Villa Langkawi, Langkawi Island, Malaysia, 15-16 Dec2021

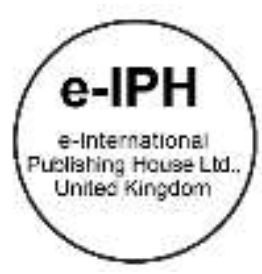

\section{Particular Characters in Heritage Tourism to Attract Visitors: A comparative study in Sumatra, Indonesia}

\author{
Nurlisa Ginting ${ }^{1,2,3}$, Nurinayat Vinky Rahman ${ }^{1,2,3}$, Achmad Delianur Nasution ${ }^{1}$, Julaihi Wahid ${ }^{4}$ \\ ${ }^{1}$ Department of Architecture, Faculty of Engineering, Universitas Sumatera Utara, Medan, Indonesia, \\ ${ }^{2}$ Lake Toba \& Sustainable Tourism Working Group, Universitas Sumatera Utara, Medan, Indonesia, \\ ${ }^{3}$ Monitoring Centre of Sustainable Tourism Observatory (MCSTO), Universitas Sumatera Utara, Medan, Indonesia, \\ ${ }^{4}$ Department of Architecture, Faculty of Built Environment, Universiti Malaysia Sarawak, Sarawak, Malaysia
}

nurlisa@usu.ac.id, n.vinky@usu.ac.id, a.delianur@usu.ac.id, wjulaihi@unimas.m

Tel: +62811608102

\begin{abstract}
Sumatra is one of the provinces in Indonesia that has great heritage tourism potential. The existence of attractive cultural buildings and traditional transportation is the particular character of heritage tourism. Heritage tourism significant benefits the economy and quality of life by showing the particular character of local people and culture. This study was conducted to compare particular characters with similar heritage tourism in Sumatra using a concurrent mixed-method. This study indicates monumental historical buildings and traditional transportation with particular characters significantly attract tourists and influence their intention to visit and revisit.
\end{abstract}

Keywords: Heritage tourism; particular character; distinctiveness; attract visitors

eISSN: 2398-4287@ 2021. The Authors. Published for AMER ABRA cE-Bsby e-International Publishing House, Ltd., UK. This is an open access article under the CC BYNCND license (http://creativecommons.org/licenses/by-nc-nd/4.0/). Peer-review under responsibility of AMER (Association of Malaysian Environment-Behaviour Researchers), ABRA (Association of Behavioural Researchers on Asians/Africans/Arabians) and CE-Bs (Centre for Environment-Behaviour Studies), Faculty of Architecture, Planning \& Surveying, UniversitiTeknologi MARA, Malaysia.

DOI: https://doi.org/10.21834/ebpj.v6i18.2995

\subsection{Introduction}

Tourism contributes significantly to the economic sector by increasing the country's foreign exchange (Ginting, 2016). Tourism and recreation activities positively impact the economies of a country or city (Rogerson \& Van der Merwe, 2016; Ginting \& Wahid, 2017). In addition, tourism is an effective tool for poverty alleviation and ensuring economic growth and equity (Shankar, 2015). Promoting tourism by highlighting particular characters is one way to overcome the economic downturn and can become a prosperous area again. For years tourism has been promoted in Indonesia. Initially, promotions were carried out to attract visitors and introduce culture to the general public (Mitchell \& Shannon, 2018). Promoting heritage tourism plays an important role in the city because the heritage resources offered to attract many visitors (Su et al., 2018), especially when it highlights a particular character.

Cities usually have a long history of socio-cultural, economic and political activities (Su et al., 2018). History leaves an important legacy, including historical buildings, historical objects, past transportation, cultural activities and city sights. The cultural and historical diversity in Sumatra can become great heritage tourism. The significant benefit of heritage tourism helps boost the economy by showing the particular characteristics of local people and culture (Eladway et al., 2020). In particular, urban cultural heritage tourism has particular characters (Kisusi \& Masele, 2019). Medan, Bukittinggi, and Siak have a similar history in Sumatra with their respective potentials. Often, visitors find it difficult to distinguish the history of one heritage tourism destination from another. A particular character makes it easier for tourists to

eISSN: 2398-4287@ 2021. The Authors. Published for AMER ABRA CE-Bsby e-International Publishing House, Ltd., UK. This is an open access article under the CC BYNCND license (http://creativecommons.org/licenses/by-nc-nd/4.0/). Peer-review under responsibility of AMER (Association of Malaysian Environment-Behaviour Researchers), ABRA (Association of Behavioural Researchers on Asians/Africans/Arabians) and CE-Bs (Centre for Environment-Behaviour Studies), Faculty of Architecture, Planning \& Surveying, UniversitiTeknologi MARA, Malaysia.

DOI: https://doi.org/10.21834/ebpj.v6i18.2995 
distinguish these tours. Also, Sumatera is rich in historical and cultural heritage, which is reflected in local wisdom. Therefore, tourist destinations in Sumatera need to be supported by concepts that follow particular characters in the area. Knowing a particular character is meant to attract visitors by promoting that particular character. Therefore, this study aims to compare the particular characters of similar heritage tourism in Medan, Bukittinggi and Siak. These findings will show the differences in particular characters of heritage building and traditional transportation on similar heritage tourism in Sumatra to influence and attract tourists to visit heritage tourism in Sumatra. Also, this research is expected to provide a guide to the policymakers and destination management on how to provide the facilities, services, and support for the development of heritage tourism.

\subsection{Literature Review}

\subsection{Heritage Tourism}

Heritage tourism is one of the important components in the tourism industry. Heritage tourism offers cultural, historical, and natural resources in cities by involving people in their communities (Shankar, 2015). Heritage tourism is a potential heritage resource inherited from the past to present and future generations, including objects, places, events, people, and phenomena (Timothy, 2018). Heritage tourism provides education to visitors about history, culture, and traditions (Shankar, 2015). Usually, these tourist visitors are motivated by the attraction of heritage objects, cultural heritage buildings, specific programs offered, and art attractions (Staiff, 1999). Heritage tourism in cities can increase tourist satisfaction by providing a particular characteristic or uniqueness of heritage tourism (McCabe, 2004).

Heritage tourism is divided into, i.e. tangible and intangible (Eladway et al., 2020; Qiu \& Zhang, 2021). Tangible heritage includes ancient buildings, temples, museums, or other artefacts presented and offered to visitors or tourists (Jaelani, 2016). Meanwhile, intangible heritage elements include traditional dance, music, drama, and folklore (Qiu \& Zhang, 2021). Heritage tourism is often concerned with tangible historical buildings and monuments, but heritage tourism can also relate to intangible historical aspects such as culture. Heritage buildings' sustainability conservation and development are important to maintain a tourist attraction.

\subsection{Particular Characters}

Distinctiveness is a particular characteristic of a place and the uniqueness created by the local community (Lalli, 1992). The relationship between local culture and the environment produces a particular character in each area (Dwijendra, 2019). The particular character in that place is the social, cultural and heritage values that can be seen through the physical manifestation of the environment (Ginting \& Wahid, 2017). A person's experience is developed through the relationship between memories, influenced by particular characters in the environment (Kim, 2014). A person's perception can arise when experiencing a memorable direct experience. When the place has a particular character (different from the other place), it will positively affect perception (Ginting \& Wahid, 2017).

The success of developing heritage tourism depends on the number of tourists visiting. One of the attractions of the urban heritage area is the image and particular characters of the area. Strong images and particular characteristics of heritage tourism are easy to identify and positively impact visitor satisfaction (Riza et al., 2012). The particular character offered will make it easier for tourists to remember the place, and places with the same object will create boredom. Historic buildings and traditional transportation give a particular character to a place (Ginting \& Wahid, 2017). Particular characters can be an attraction because they only exist or can only be enjoyed in certain areas and at certain times (Rif'an, 2016). Usually, it cannot be imitated by destinations elsewhere. Since urban areas have a particular character in historical buildings and typical traditional transportation; tourists become interested in visiting the area.

Table 1 Aspects of Particular Characters

\begin{tabular}{ll}
\hline \multicolumn{1}{c}{ Particular Characters } & \multicolumn{1}{c}{ Indicator } \\
\hline Cultural Buildings & $\begin{array}{l}\text { Respondent's perception of cultural building in the } \\
\text { research area }\end{array}$ \\
\hline $\begin{array}{l}\text { Respondent's perception of diversity of cultural } \\
\text { building in the research area }\end{array}$ \\
\hline Traditional Transportation & $\begin{array}{l}\text { Respondent's perception of traditional transportation } \\
\text { in the research area }\end{array}$ \\
\hline $\begin{array}{l}\text { Respondent's perception of diversity of traditional } \\
\text { transportation in the research area }\end{array}$ \\
\hline
\end{tabular}

\subsection{Methodology}

\subsection{Research Area}

This research was conducted in Sumatran cities; there are famous for heritage tourism destinations. Medan, Bukittinggi and Siak have heritage tourism with unique and particular characters that can attract visitors (Fig. 1). Heritage tourism researched in Medan City is Maimun Palace, Sri Deli Park, Al Mahsun Grand Mosque, London Sumatra, Medan City Hall, Tjong A Fie's House, Bank Indonesia and the Post Office. These tourist destinations are representative of the city's relics of the past in Medan. The heritage tourism area in Medan is close to each other from one destination to another. Tourist destinations from the deli sultanate in Medan include the Maimun Palace, Taman Sri Deli and the Al Mahsun Grand Mosque. 
In Bukittinggi, the heritage tourism studied included Jam Gadang, Bung Hatta's Birth House, Pagaruyung Palace, Japanese Hole and the Fort de Kock. Jam Gadang is a landmark of Bukittinggi with a height of 26 meters. Bung Hatta Birth House was built to commemorate and picture where Bung Hatta was born. It is a simple house that provides a lot of education to visitors. Another destination, Pagaruyung Palace, is a relic of the most popular Pagaruyung Kingdom. Pagaruyung Palace is a building with the concept of a rectangular Gadang house with a distinctive Minangkabau roof that protrudes like a buffalo horn. Also, there is a Japanese Hole and the Fort de Kock, which was built during the Japanese and Dutch colonial times. This destination was originally built to defend its territory.

Then, heritage tourism researched in Siak includes Siak Sri Indrapura Palace, Kato Ship, Tangsi Holland and Syahabudin Great Mosque. This heritage tourism area is also close from one destination to another. Siak Sri Indrapura Palace, Kato Ship, and Syahabudin Great Mosque are relics of the famous Siak kingdom. Siak Sri Indrapura Palace has a unique building with Arabic, Malay and European patterns. Also, there is a Dutch Tangsi located on the side of the Siak River, which is a Dutch heritage fort. The Dutch Tangsi building is typical of Dutch architecture, thus providing a strong memory for visitors about tourist attractions.

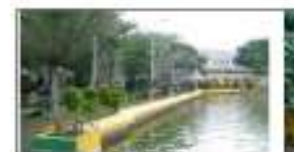

Si DeliPark

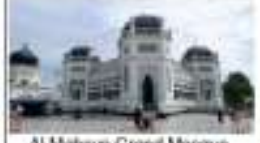

AN Marisun Griand Moszue

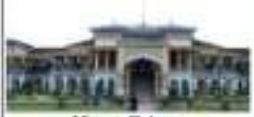

Mimun Palsose

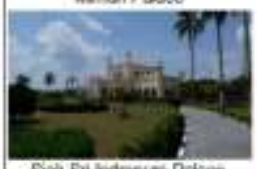

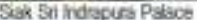
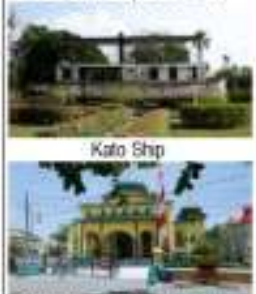

Byahabuin Gans Moopue

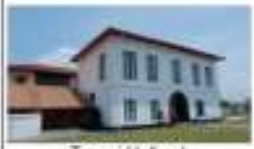

Tangritholind

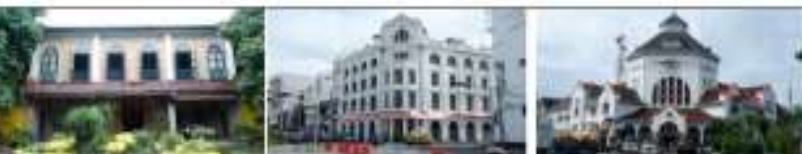

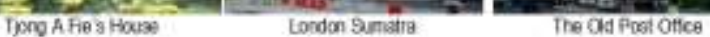
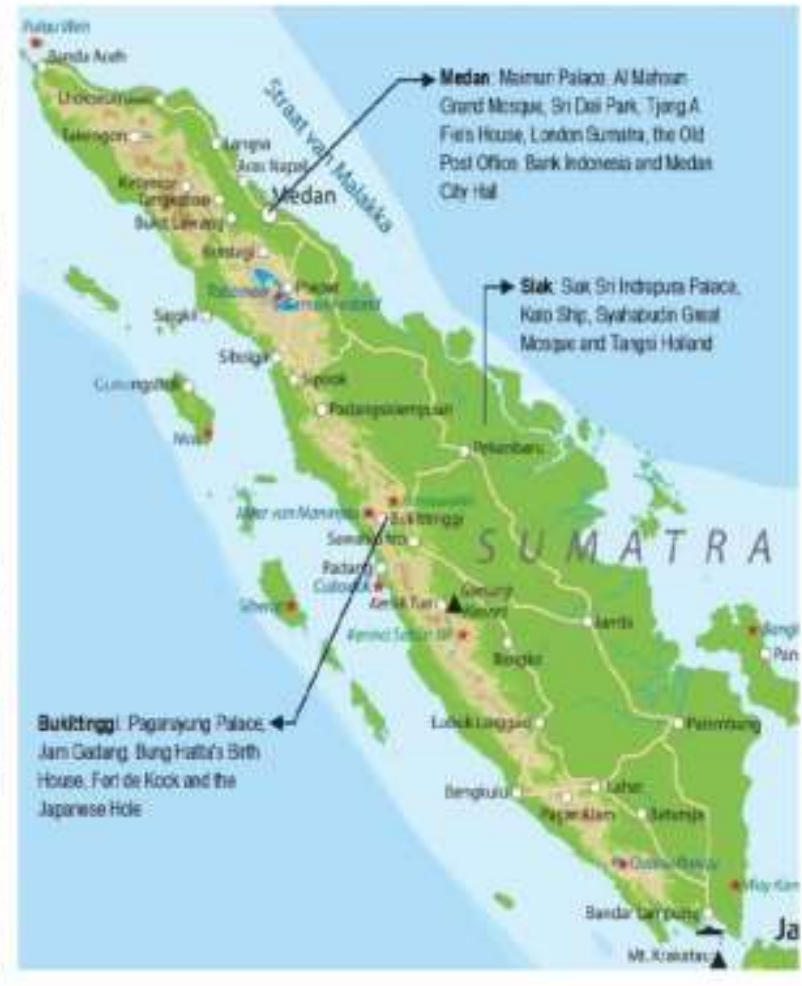

Fig. 1. Research Area

(Source: Author)

\subsection{Methods}

This study adopted a mixed method by collecting qualitative and quantitative data. Triangulation of data collection (surveys, interviews, and questionnaires) in the study was conducted to provide a broad and in-depth understanding of the specific character of heritage tourism. Observations of heritage tourism tourist destinations have been carried out in Medan, Bukittinggi and Siak. Also, in-depth interviews were conducted with 12 tourism stakeholders such as academics, travel agents, government and managers of heritage tourism destinations in Medan, Bukittinggi and Siak. Researchers have distributed 150 questionnaires to respondents at heritage tourism research sites for questionnaires. The questionnaire contained four sections: respondent's profile, travel motivations, respondents' perceptions of typical cultural buildings and respondents' perceptions of typical traditional transportation associated with particular characters in heritage tourism. The questionnaire's respondents' criteria are local people and tourists who have visited heritage tourism in the research area. The questionnaire was measured on a five-point scale from strongly agree (5) to disagree (1). The data collection results are statistically processed in the SPSS application to assess particular characters that exist in each heritage tourism destination. Aspects of particular characters of heritage tourism are analyzed on indicators: typical cultural buildings and typical traditional transportation. The limitation of the study is the observation process in heritage tourism areas temporarily closed during the pandemic. Another limitation of the study is that it only examines two particular character variables that might make visitors interested in heritage tourism. Other variables related to a particular character that may influence visitor interest should be explored. 


\subsection{Findings}

\subsection{Respondent Profile}

This study involved 150 respondents consisting of 50 respondents from each city in Medan, Bukittinggi and Siak. Respondents in each city consisted of 25 local people and 25 tourists. Respondent profiles were classified into age, gender, and education. The majority of respondents were aged between $18-24$ years $(48 \%)$, followed by $25-49$ years $(34.67 \%)$ and $50-65$ years $(17.33 \%)$. Only $35.33 \%(n=53)$ of survey respondents were male, while $64.67 \%$ ( $n=97)$ were female. Education between one individual and another is certainly not the same, so that it affects one's behaviour in making decisions (Ballantyne \& Packer, 2011). Therefore, the education of respondents is an important thing to know. In this study, 59.33\% of respondents with the latest education were Bachelor S1, 28.67\% High School, 10.67\% Masters S2 and $1.33 \%$ Doctoral S3.

\subsection{Particular Characters Aspect}

Particular characters become city representatives on heritage tourism in Medan, Bukittinggi and Siak. Overall, this study finds that particular characters in tourism heritage positively respond to local people and tourists. Table 2 shows the mean score of 8 items from the aspect of the particular characters. "The historical buildings and sites are very interesting" is the question with the highest average ratings (Tabel 2). While "the reason I visit is typical traditional transportation" is the question with the lowest average ratings. It shows that respondents agree that historical buildings are certain characters most readily visible in heritage tourism. Meanwhile, public transportation gets the lowest score due to the lack of quality transportation and finding transportation to heritage tourism.

Table 2. The Average Value of The Particular Characters Aspects of Heritage Tourism

\begin{tabular}{|c|c|c|c|c|c|c|c|c|c|}
\hline \multirow{2}{*}{$\begin{array}{c}\text { Particular } \\
\text { Character } \\
\text { Aspect }\end{array}$} & \multicolumn{2}{|r|}{ Statements } & \multicolumn{2}{|c|}{ Medan } & \multicolumn{2}{|c|}{ Bukittinggi } & \multicolumn{2}{|c|}{ Siak } & \multirow{2}{*}{ Mean } \\
\hline & & & LP & $T$ & LP & $T$ & LP & $T$ & \\
\hline \multirow{4}{*}{$\begin{array}{l}\text { Cultural } \\
\text { Building }\end{array}$} & PC1 & $\begin{array}{l}\text { The historical buildings and sites are very } \\
\text { interesting }\end{array}$ & 3,92 & 4,12 & 4,28 & 4,32 & 4,60 & 4,32 & 4,26 \\
\hline & PC2 & $\begin{array}{l}\text { The reason I visited is the beauty of the } \\
\text { building's heritage }\end{array}$ & 3,96 & 4,28 & 4,20 & 4,24 & 4,32 & 4,24 & 4,21 \\
\hline & PC3 & $\begin{array}{l}\text { Moving heritage objects (figures, paintings, } \\
\text { photos, documents, archives, etc.) are very } \\
\text { interesting }\end{array}$ & 3,64 & 3,80 & 4,16 & 3,84 & 4,04 & 4,08 & 3,93 \\
\hline & PC4 & $\begin{array}{l}\text { The reason I visited is movable heritage } \\
\text { objects (figures, paintings, photos, documents, } \\
\text { archives, etc.) }\end{array}$ & 3,64 & 3,92 & 3,72 & 3,52 & 4,04 & 4,04 & 3,81 \\
\hline \multirow{4}{*}{$\begin{array}{l}\text { Local } \\
\text { Transportation }\end{array}$} & PC5 & $\begin{array}{l}\text { The typical traditional transportation in this area } \\
\text { is very interesting }\end{array}$ & 2,80 & 2,84 & 4,08 & 3,56 & 2,88 & 2,84 & 3,17 \\
\hline & PC6 & $\begin{array}{l}\text { The reason I visit is typical traditional } \\
\text { transportation }\end{array}$ & 2,52 & 2,64 & 3,56 & 3,00 & 2,76 & 2,76 & 2,87 \\
\hline & PC7 & $\begin{array}{l}\text { I enjoy typical traditional transportation as a } \\
\text { tourist attraction }\end{array}$ & 2,76 & 2,88 & 3,84 & 3,32 & 2,72 & 2,76 & 3,05 \\
\hline & PC8 & $\begin{array}{l}\text { Typical traditional transportation related to } \\
\text { culture and history }\end{array}$ & 2,92 & 2,96 & 3,68 & 3,52 & 2,92 & 2,92 & 3,15 \\
\hline \multicolumn{3}{|c|}{$\begin{array}{c}\text { Value Format: } 5 \text { = strongly agree \& } 1 \text { = strongly disagree } \\
L P=\text { Local People, } T=\text { Tourist }\end{array}$} & 3,27 & 3,43 & 3,94 & 3,67 & 3,54 & 3,50 & 3,56 \\
\hline
\end{tabular}

\subsection{Discussion}

\subsection{Typical Cultural Buildings}

Historic buildings and objects have attracted many visitors. Historic buildings will give a sense of pride to visitors and local people (Ginting et al., 2017). The buildings in the three study areas have particular characteristic facades and history, so it needs to be preserved. Comparing the three cities, we found that heritage buildings in Medan $(L=3.92 ; T=4.12)$, Bukittinggi $(L=4.28 ; T=4.32)$ and Siak $(L=$ $4.60 ; T=4.32)$ is interesting. Also, they said that the beauty of heritage buildings in Medan $(L=3.96 ; T=4.28)$, Bukittinggi ( $L=4.20 ; T=$ 4.24) and Siak ( $L=4.32 ; T=4,24)$ became their reason for visiting. Maimun Palace (Medan), Pagaruyung Palace (Bukittinggi) and Siak Sri Indrapura Palace (Siak) are the most popular palace buildings in their history. The beauty of heritage buildings can be seen in particular characters of the Maimun Palace, which is a heritage building of the Deli Sultanate. Maimun Palace is an icon and pride of the city of Medan. This palace adopts Malay, Mogul, Arabic, Indian and European architectural styles. Typical Middle Eastern architecture also adds to the elegance and splendour of the Maimun Palace. Maimun Palace is a two-story building dominated by yellow, the typical colour of Malay royalty. The palace's roof is curved or similar to an inverted boat, which is a particular character of this palace building. The particular character of the combination of Malay and European architecture in the Maimun Palace can be seen from the shape of the building, which has many pillars and a distinctive roof.

In addition, there is the Pagaruyung Palace in Bukittinggi, which is a Minangkabau traditional house building or the Gadang House. This palace consists of three floors with a Gonjong roof. The roof resembling a horn is a particular character of traditional Minangkabau architecture. Gonjong roof that points up / to the sky is interpreted as an interaction with God. "Pagaruyung Palace was burned in 2007. 
Only about $15 \%$ of heritage objects have survived; other objects are replicas. However, the government managed to rebuild the palace. The beauty and history of the palace building attract visitors to come and revisit." (Main respondent: Bukittinggi District Government Leader)

Then, the Siak Sri Indrapura Palace was designed by German architects. It attracts visitors because it adopts Arabic, Malay, and European architectural styles. This two-story building is the residence of the previous king of Siak. In this palace, there are six statues of eagles that adorn the top of the palace and eight cannons scattered on the palace grounds. Some unique ornaments and roofs add beauty in the three heritage buildings become a particular character. Ornaments in buildings usually have different meanings and symbols for something. Visible particular characters and symbols with historical value will advance tourism because they create pride for visitors and local people (Ginting et al., 2019).

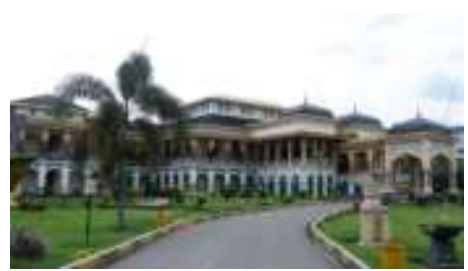

Maimun Palace, Medan

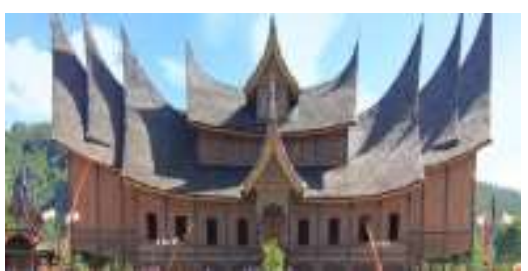

Pagaruyung Palace, Bukittinggi

Fig. 2. Cultural Building of Heritage Tourism (Source: Author)

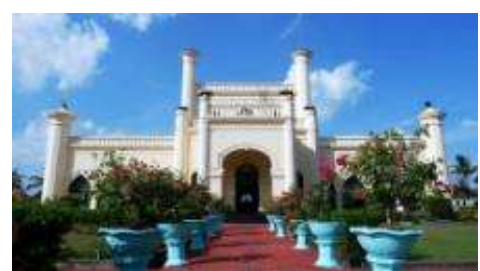

Siak Sri Indrapura Palace, Siak

Respondents also thought that movable heritage objects in heritage tourism areas in Medan $(L=3.64 ; T=3.80)$, Bukittinggi $(L=4.16$; $T=3.84)$ and Siak ( $L=4.04 ; T=4.08)$ is interesting. Also, they said heritage objects in Medan $(L=3.64 ; T=3.92)$, Bukittinggi ( $L=3.72 ; T=$ 3.52) and Siak ( $L=4.04 ; T=4.04)$ is also one of the reasons they visit heritage tourism. The existence of object inheritance gives a particular character of a place that will lead attract visitors. Inheritance objects contain history that must be protected and preserved. Heritage objects can be found at Maimun Palace, Pagaruyung Palace and Siak Sri Indrapura Palace. The heritage objects include traditional clothes, documents, photographs of the past, paintings, furniture, musical instruments, statues and weapons (swords). The object has a particular character that cannot be found anywhere else, thus providing memory to visitors (Rif'an, 2016).

\subsection{Typical Traditional Transportation}

Typical traditional transportation can be an attraction in the heritage tourism area. Based on the survey results in heritage tourism areas, the typical modes of transportation in Medan $(L=2.80 ; T=2.84)$ and Siak $(L=2.88 ; T=2.84)$ are less attractive. It is because, in the heritage tourist area, there is no typical transportation found. There is only public transportation, motorcycle taxis, taxis, and rickshaws in this area. Thus, the typical mode of transportation is not one of the reasons for visitors to visit heritage tourism in Medan $(\mathrm{L}=2.52 ; \mathrm{T}=$ 2.64) and Siak $(L=2.76 ; T=2.76)$. At the sultanate time, the traditional transportation used were horses and ships. This mode of transportation can be used as a typical tourist attraction. However, visitors cannot enjoy the typical modes of transportation in Medan $(L=$ 2.76; $T=2.88)$ and Siak $(L=2.72 ; T=2.76)$ because they are not used as tourist attractions. Meanwhile, according to respondents, the typical mode of transportation in Medan $(L=2.92 ; T=2.96)$ and Siak $(L=2.92 ; T=2.92)$ is less related to the culture and history of the area, so it is not an increase visitor interest in the area.

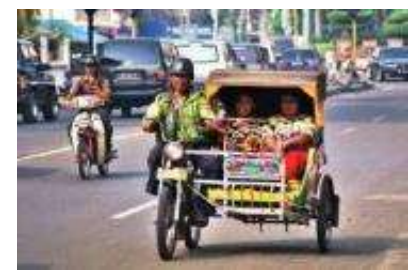

Medan

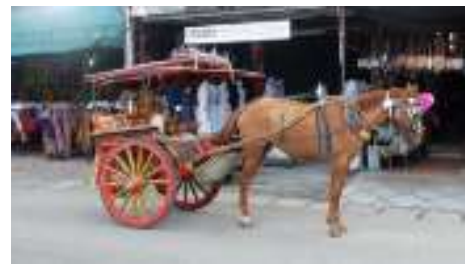

Bukittinggi

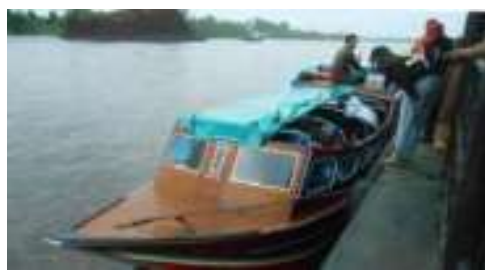

Siak

Fig. 3. Local Transportation in Heritage Tourism (Source: Author)

In the Bukitttinggi heritage tourism area $(L=4.08 ; T=3.56)$, there is typical traditional transportation called a Bendi. Bendi is a traditional Minangkabau carriage drawn by a horse or Delman. The typical traditional transportation in Bukittinggi $(\mathrm{L}=3.56$; $\mathrm{T}=3.00)$ is one of the reasons peoples visit heritage tourism. In the Dutch colonial era, Bendi was a vehicle for wealthy merchants and prominent people in society. With the Bendi, visitors can enjoy typical traditional transportation that is used as a tourist attraction $(L=3.84 ; T=3.32)$. Also, respondents $(L=3.68 ; T=3.52)$ agree that the Bendi is typical traditional transportation related to the culture and history of the area. "Bendi is a mode of transportation in the past. Also, Bendi attracts many visitors to Bukittinggi. With Bendi, tourists can surround tourist attractions in Bukittinggi. The government is trying to maintain and preserve the Bendi as a transportation asset." (Main respondent: Bukittinggi District Government Leader). Bendi has a function as a mode of transportation and recreation mode. In heritage tourism, Bendi attracts many visitors who want to try this type of traditional transportation, especially children (Joewono \& Kubota, 2005). 


\subsection{Conclusion \& Recommendations}

The particular character of heritage tourism is one of the important elements in creating the identity and image of the city. This study found that heritage buildings and objects have the strongest particular characteristic in heritage tourism and play an important role in attracting visitors. However, typical traditional transportation does not affect a particular characteristic in heritage tourism areas. Typical traditional transportation is an interesting cultural heritage for visitors. Traditional transportation has not been used as a tourist attraction in some cities. The use of traditional transportation as an attraction can attract visitors to travel. Therefore, the government should make a policy to develop traditional transportation. Local people and governments must be committed to maintaining, managing, and preserving heritage tourism destinations by highlighting particular characters. This research is still limited to aspects of particular characters. So, further research is a preservation study based on the characteristics of heritage tourism.

\section{Acknowledgement}

The authors wish to thank the Ministry of Research and Technology and the Higher Education Republic of Indonesia, and Universitas Sumatera Utara for their invaluable support of this study. The support is under the research grant DPRM of the Year 2021 Contract Number: 201/UN5.2.3.1/PPM/KP-DRPM/2021.

\section{Paper Contribution to Related Field of Study}

The paper's contribution is related to the fields of urban planning and tourism, especially in increasing the understanding and development of particular characters in heritage tourism.

\section{References}

Ballantyne, R., \& Packer, J. (2011). Using tourism free-choice learning experiences to promote environmentally sustainable behaviour: the role of post-visit 'action resources'. Environmental Education Research, 17(2), 201-215.

Brouder P (2012) Creative outposts: Tourism's place in rural innovation. Tourism Planning and Development 9: 383-396.

Dwijendra, N. K. A. (2019). Vernacular Inculturation on the Architecture of the Church in Bali, Indonesia (Case Study: Pniel Blimbingsari Christian Church, Jembrana, Bali). Journal of Social and Political Sciences. 2(3).

ELADWAY, S. M., AZZAM, Y. A., \& AL-HAGLA, K. S. (2020). ROLE OF PUBLIC PARTICIPATION IN HERITAGE TOURISM DEVELOPMENT IN EGYPT: A CASE STUDY OF FUWAH CITY. WIT Transactions on Ecology and the Environment, 241, 27-43

Ginting, N., Rahman, N. V., \& Nasution, A. D. (2019). Aspects of self-esteem in the tourism development in Karo regency, North Sumatera, Indonesia. Journal of Urban \& Regional Analysis, 11(2).

Ginting, N., Rahman, N. V., \& Nasution, A. D. (2017). Increasing tourism in Karo District, Indonesia based on place identity. Environment-Behaviour Proceedings Journal, 2(5), 177-184.

Ginting, N., \& Wahid, J. (2017). Defining distinctiveness aspect of place identity in urban heritage tourism. IPTEK Journal of Proceedings Series, 3(3)

Jaelani, A. (2016). Islamic tourism development in Cirebon: The study heritage tourism in Islamic economic perspective. Journal of Economics Bibliography, 3(2).

Joewono, T. B., \& Kubota, H. (2005). The characteristics of paratransit and non-motorized transport in Bandung, Indonesia. Journal of the Eastern Asia Society for Transportation Studies, 6, 262-277.

Kisusi, R. L., \& Masele, J. J. (2019). Efficacy of public awareness strategies for promoting existing cultural heritage tourism assets in Dar es Salaam. Journal of Heritage Tourism, 14(2), 117-137.

McCabe, S., \& Stokoe, E. H. (2004). PLACE AND IDENTITY IN TOURISTS'ACCOUNTS. Annals of Tourism Research, 31(3),601-622.

Mitchell, C. J., \& Shannon, M. (2018). Exploring cultural heritage tourism in rural Newfoundland through the lens of the evolutionary economic geographer. Journal of Rural Studies, 59, 21-34.

Rif'an, A. A. (2016). Tourism Components and Tourists Characteristic of Prambanan Temple as The World Culture Heritage Site in Yogyakarta, Indonesia. International Journal of Tourism and Hospitality Study, 1(1)

Rogerson, C. M., \& Van der Merwe, C. D. (2016). Heritage tourism in the global South: Development impacts of the cradle of humankind world heritage site, South Africa. Local Economy, 31(1-2), 234-248.

Shankar, S. (2015). Impact of heritage tourism in India-A case study. International Journal of Innovative Research in Information Security, 6(2), 59-61.

Staiff, R. (1999). Tourism and Western visual culture. In Australian Tourism and Hospitality Education (CAUTHE) 9th National Research Conference, Adelaide,February.

Su, R., Bramwell, B., \& Whalley, P. A. (2018). Cultural political economy and urban heritage tourism. Annals of Tourism Research, 68, 30-40.

Timothy, D. J. (2018). Making sense of heritage tourism: Research trends in a maturing field of study. Tourism Management Perspectives, 25, 177-180. 